\title{
O Projeto ENEM e a formação inicial de professores: a construção do conhecimento escolar em um subprojeto Biologia do PIBID
}

The ENEM Project and initial teacher education: the school knowledge construction in a Biology subproject of PIBID

Marcos Ferreira Josephino Maria Cristina Ferreira dos Santos

\begin{abstract}
Resumo: Trata-se de um estudo sobre o desenvolvimento do Projeto ENEM, no âmbito do subprojeto Biologia do PIBID, em uma escola pública no município de São Gonçalo, Rio de Janeiro, de 2018 a 2019. O estudo teve natureza qualitativa, tendo sido realizada a pesquisa-ação. Foram tomados como materiais empíricos observações, relatos e materiais didáticos produzidos neste período. Durante os anos de 2018 e 2019 houve o planejamento e desenvolvimento de aulas e materiais didáticos pelos licenciandos bolsistas sobre temas frequentes no ENEM e vestibulares, tais como: vírus, bactérias, DNA, ecologia, genética mendeliana, origem da vida, evolução biológica, respiração celular, fotossíntese, fisiologia humana, morfologia vegetal, histologia e programas de saúde. O número de estudantes da educação básica inscritos no ENEM e em vestibulares foi maior do que em anos anteriores, sendo vários aprovados em universidades públicas. Os licenciandos bolsistas destacaram a relevância deste Programa para a formação inicial docente e educação básica.
\end{abstract}

Palavras-chave: Formação docente. Ensino de Biologia. ENEM. PIBID.

Abstract: This is a study on the development of the ENEM Project, within the subproject Biology of PIBID, in a public school in the municipality of São Gonçalo, Rio de Janeiro, from 2018 to 2019. The study was qualitative in nature and was carried out at action research. Observations, reports and didactic materials produced in this period were taken as empirical materials. During the years of 2018 and 2019 there was the planning and development of classes and didactic materials by the undergraduates on frequent theme at ENEM and entrance exams, such as: viruses, bacteria, DNA, ecology, Mendelian genetics, origin of life, biological evolution, cellular respiration, photosynthesis, human physiology, plant morphology, histology and health programs. The number of school students enrolled in ENEM and in entrance exams was greater than years before, many being approved by public universities. The teacher training course scholarship students highlighted the relevance of PIBID for initial teacher training, high school and elementary education.

Keywords: Teacher training. Biology education. ENEM. PIBID.

\section{Introdução}

Além do processo de socialização e da experiência com os futuros colegas de profissão, é na escola que o licenciando terá a oportunidade de colocar em prática os conhecimentos e as metodologias aprendidas no ambiente acadêmico. De acordo com Tardif (2014, p. 80), a carreira 
profissional se inscreve em "[...] uma realidade social e coletiva e os indivíduos que a exercem são membros de categorias coletivas de atores que os precederam e que seguiram a mesma trajetória". Nóvoa (2019, p. 201) defende a importância da presença articulada de três fatores na formação profissional docente: as instituições universitárias de formação de professores, as políticas educativas e os professores de educação básica. A formação profissional do licenciando se dá no contato direto com profissionais que atuam na escola; tais vínculos entre os licenciandos e "[...] os que já são profissionais" conformam novos modelos de formação de professores (NÓVOA, 2019, p. 206).

Langui e Nardi (2012, p. 20) consideram três trajetórias formativas como principais na vida profissional dos professores: trajetória formativa docente inicial, trajetória formativa docente intermediária e trajetória formativa docente na carreira. A trajetória formativa inicial está relacionada às experiências de vida pessoal, familiar e escolar, ocorridas antes da escolha da carreira docente e que, de alguma maneira, terão influência na identidade profissional do professor. A trajetória formativa docente intermediária está relacionada aos conhecimentos elaborados com base em conteúdos e práticas de formação acadêmica e a trajetória formativa docente na carreira ocorre após o término do curso de licenciatura e prossegue ao longo da carreira profissional.

De acordo com Tardif (2014, p. 64 e 67 ), os saberes dos professores provêm de experiências e lugares anteriores à carreira profissional (da família, da escola que o formou e de sua cultura pessoal). As influências de um parente professor, as lembranças das qualidades e atitudes marcantes de um exprofessor, o gosto por ensinar contribuem para a "construção do Eu profissional", em que cada professor elabora o seu próprio perfil profissional. Este autor afirma que:

O início da carreira docente é acompanhado também de uma fase crítica, pois é a partir das certezas e dos condicionantes da experiência prática que os professores julgam sua formação universitária anterior. Segundo eles, muita coisa da profissão se aprende com a prática, pela experiência, tateando e descobrindo, em suma, no próprio trabalho. Ao estrearem em sua profissão, muitos professores se lembram de que estavam mal preparados, sobretudo para enfrentar as condições de trabalho difíceis, notadamente no que se refere a elementos 
como o interesse pelas funções, a turma de alunos, a carga de trabalho etc. Foi então, através da prática e da experiência que eles se desenvolveram em termos profissionais (TARDIF, 2014, p. 86).

Como uma forma de contribuir para uma maior aproximação entre universidade e escola na formação inicial, o Programa Institucional de Bolsas de Iniciação à Docência (PIBID) foi estabelecido pelo Ministério da Educação (MEC), visando proporcionar aos alunos dos cursos de licenciatura a imersão no cotidiano das escolas públicas, vivenciando experiências no futuro ambiente de trabalho durante a sua formação universitária.

Este trabalho é um relato de experiência que tem como objetivo discutir e refletir sobre as atividades realizadas no Projeto ENEM, desenvolvido em uma escola pública no município de São Gonçalo, no estado do Rio de Janeiro, durante os anos de 2018 e 2019, no âmbito do subprojeto Biologia do PIBID, por um professor da educação básica, bolsistas licenciandos em Ciências Biológicas e uma professora de uma universidade pública. Além disso, buscouse também refletir sobre os impactos do projeto na formação desses bolsistas licenciandos.

\section{PIBID: aspectos históricos e valorização do magistério}

O PIBID teve início com a Portaria n 38/2007 (BRASIL, 2007), assinada pelo ministro Fernando Haddad, em 12 de dezembro de 2007. Por meio deste programa, o Ministério da Educação tinha como objetivo incentivar a carreira de magistério em áreas com carência de professores na educação básica, como ciências, biologia, química, física e matemática. Entre as expectativas incluía-se o aumento das médias das escolas participantes do Exame Nacional do Ensino Médio (ENEM). Também a ação buscava atender ao plano de metas "Compromisso Todos pela Educação", traçado no Plano de Desenvolvimento da Educação (PDE), de elevar o índice de desenvolvimento da Educação Básica (Ideb) até 2022. O Programa, vinculado à Coordenação de Aperfeiçoamento Pessoal de Nível Superior (CAPES), conta com o trabalho em parceria das universidades e professores das escolas envolvidas (BRASIL, MEC/PDE, 2007). Para atender tais metas, no Artigo $n^{\circ} 3$ da Portaria $n^{\circ}$ 
38/2007 (BRASIL, 2007) estabelece-se que parte do estágio de iniciação à docência (ID) deve ser cumprida em escolas com baixos resultados no Ideb e baixas médias no ENEM.

Foi por meio da Lei $n^{\circ} 11.273$ de 2006 (BRASIL, 2006) que se tornou possível a existência de programas como o PIBID, com a oferta de bolsas de estudo e pesquisa a professores pela Coordenação de Aperfeiçoamento de Pessoal de Nível Superior (CAPES), do Ministério da Educação, na formação inicial e continuada de professores para a educação básica. Com o Decreto 7.219/2010 iniciou-se a proposição de um programa de valorização dos profissionais do magistério, concretizando-se como uma política de Estado por meio da lei $n^{\circ}$ 12. 796/2013 (RODRIGUES et al., 2014). Regulamentado pela Portaria 096/2013 (CAPES, 2013), o PIBID tem como base legal as Leis $n^{\circ}$ 9.394/1996 (BRASIL, 1996) e $n^{\circ} 12.796 / 2013$ (BRASIL, 2013) o e o Decreto $n^{\circ}$ 7.219/2010 (BRASIL, 2010).

O Plano Nacional de Educação (PNE) aprovado pela Lei $n^{\circ}$ 13.005/2014 estabelece como uma das estratégias na meta 12 a garantia de "[...] oferta de educação superior pública e gratuita prioritariamente para a formação de professores e professoras para a educação básica, sobretudo nas áreas de ciências e matemática" (BRASIL, 2014). A meta 17 do PNE trata da valorização profissional do magistério da educação básica nas escolas públicas. Essas duas metas se entrelaçam às finalidades do PIBID.

Segundo o MEC (BRASIL, 2018), o PIBID distingue-se de outras políticas anteriormente implantadas por permitir uma maior interação entre os seus participantes: estudantes e professores da educação básica, licenciandos e professores dos cursos de licenciatura de ensino superior. Sobre os impactos positivos do PIBID, 1.267 escolas públicas foram favorecidas pela ação dos bolsistas, registrando indicação de melhoria nos resultados do Ideb nas escolas participantes. Em relação à formação docente, constatou-se a diminuição da evasão e aumento da procura dos cursos de licenciatura, bem como o reconhecimento de um novo status para esses cursos na comunidade acadêmica (BRASIL, 2018). 
Segundo Locatelli (2018, p. 312), a disponibilidade das bolsas de iniciação à docência pode ser compreendida como "Um dos principais fatores que contribuem para um impacto positivo no processo de formação docente", por possibilitar que os bolsistas com renda familiar baixa permaneçam e se dediquem aos seus respectivos cursos. Além disso, a experiência do PIBID tem gerado grupos de pesquisa, importantes debates e um intenso volume de produções acadêmicas referentes ao projeto em periódicos e eventos da área.

Por outro lado, Locatelli (2018) também aponta algumas fragilidades do Programa, como a viabilidade de o estudante trabalhador realizar o estágio de ID e a ausência de espaços nas universidades e nas escolas para o desenvolvimento das ações. Também, de acordo com o relatório avaliativo do PIBID da Fundação Carlos Chagas de 2014, o projeto atinge apenas uma pequena parte dos estudantes dos cursos de licenciatura e o valor da bolsa não chega a ser suficiente para que os bolsistas consigam cobrir suas despesas (LOCATELLI, 2018, p. 314-315).

\section{Percurso metodológico}

O estudo teve natureza qualitativa, com foco em questões humanas e sociais. Foi realizada a pesquisa-ação, que está fundamentada em experiências vivenciadas, em que o pesquisador faz observações sobre a realidade em que está inserido e tenta responder à questão investigada. Para André (2015, p. 27), a pesquisa-ação pode ser exemplificada quando um professor modifica as suas metodologias de ensino com base na análise de dados e reflexões advindas da pesquisa. Para Thiollent:

[...] a pesquisa-ação é um tipo de pesquisa social com base empírica que é concebida e realizada com estreita associação com uma ação ou com a resolução de um problema coletivo e no qual os pesquisadores e os participantes representativos da situação ou do problema estão envolvidos de modo cooperativo ou participativo (THIOLLENT, 2018, p. 14).

O estudo foi realizado nos anos de 2018 e 2019 em uma escola pública no município de São Gonçalo, no estado do Rio de Janeiro, com a participação de cerca de 30 estudantes do ensino médio; dez bolsistas e voluntários de 
Iniciação à Docência em Biologia do PIBID; um professor de Biologia da educação básica e uma professora universitária. As atividades do Projeto ENEM foram ofertadas aos estudantes das seis turmas do terceiro ano do ensino médio regular da escola em dois dias da semana, no contraturno - as aulas regulares eram realizadas de manhã e as atividades do projeto ENEM à tarde.

As visões dos licenciandos sobre as atividades foram examinadas por meio da análise de conteúdo (FRANCO, 2012), tomando-se como materiais empíricos observações e relatos produzidos neste período. Visando ao sigilo da identidade dos participantes, utilizou-se um código alfanumérico e atribuiuse a Letra L, seguido de um número arábico, para se referir aos licenciandos. Nas imagens também se atentou para o sigilo dos participantes.

\section{A chegada dos licenciandos na escola}

Os estudantes bolsistas e voluntários do PIBID do curso de licenciatura em Ciências Biológicas selecionados no Edital de 2018 chegaram à escola em agosto e permaneceram até janeiro de 2020, permanecendo três semestres imersos no ambiente escolar, participando das aulas, desenvolvendo atividades pedagógicas e uma proposta de pesquisa que contribuísse para o ensino de Biologia na educação básica.

Segundo Nóvoa (2019, p. 202), “[...] um professor não se forma nos atuais ambientes universitários, nem em ambientes escolares medíocres e desinteressantes". A parceria entre a universidade e a escola contribui para que o licenciando coloque em prática os conhecimentos teóricos aprendidos no ambiente acadêmico e interaja com os futuros colegas de profissão, que trabalham no magistério e têm a experiência de quem lida diretamente com a realidade escolar, com suas estratégias de ensino frente a tais desafios, contribuindo positivamente para a formação do futuro professor. Segundo este autor:

Não devemos nunca desvalorizar o conhecimento das disciplinas científicas (a Matemática, a História etc). Caso contrário, é impossível educar as crianças e o trabalho dos professores tende a rodar num vazio de conhecimento. 
Também não podemos desvalorizar o conhecimento pedagógico e a das ciências da educação (questões psicológicas, históricas e sociológicas, políticas educativas, metodologias e didáticas etc). No entanto, esses dois tipos de conhecimento, que organizam os currículos das licenciaturas, tendem a ignorar um terceiro gênero de conhecimento, absolutamente decisivo para formar os professores: o conhecimento profissional docente. Se não reconhecermos a existência e a importância deste "terceiro conhecimento", não conseguiremos afirmar a profissão docente como "profissão baseada no conhecimento". Se os professores estiverem unicamente dependentes de um conhecimento produzido "fora" da profissão, seja pelos cientistas das disciplinas acadêmicas, seja pelos cientistas da educação, não será possível construir uma formação de professores de nível superior. Temos estado fechados numa dicotomia redutora entre o conhecimento científico e o conhecimento pedagógico (NÓVOA, 2019, p. 204).

No primeiro contato dos licenciandos bolsistas deste subprojeto Biologia do PIBID com o ambiente escolar, pôde-se notar entusiasmo e empolgação em alguns deles, mas também em outros se percebeu aquilo que Tardif (2014, p. 82) aponta como "choque com a realidade", processo ligado à socialização profissional do professor, em que ocorre o "[...] confronto inicial com a dura e complexa realidade do exercício da profissão".

No estágio supervisionado, na formação inicial, muitas vezes não há tempo e interações para que o licenciando possa conhecer bem a escola, em suas diferentes dimensões. Os estudantes e turmas são diferentes, os professores têm diferentes formações, perspectivas disciplinares e pedagógicas e o que se adequa a uma determinada turma pode não funcionar em outra. Mellouki e Gauthier (2004) apontam o grau de complexidade que envolve o ambiente escolar e como o profissional do magistério precisa estar atento para acompanhá-lo.

Esse caráter paradoxal e altamente complexo, conotado com o social e bastante controverso da profissão docente, coloca aqueles e aquelas que a exercem no ponto de interseção das relações sociais: relações com as matérias ensinadas, com os programas, com as abordagens pedagógicas, com os livros didáticos, com a classe e com os alunos individualmente, com a direção da escola, com a Secretaria de Educação, com a equipe escolar, com os pais, com a mídia, com o passado, com o presente e com o futuro, com as ideologias sociais, com a cultura etc. Tal caráter paradoxal, compósito e complexo impõe 
inevitavelmente aos professores a obrigação de estarem sempre em situação e em estado de reflexão, de estarem sempre atentos, de analisarem as situações, de decodificarem as intenções $e$ de adivinharem $o$ significado dos comportamentos de todos os seus alunos, ao mesmo tempo em que procuram resolver as questões, dificuldades ou problemas decorrentes dessas situações, intenções e comportamentos (MELLOUKI; GAUTHIER, 2004, p. 544).

Durante três semestres letivos os licenciandos do PIBID vivenciaram as dinâmicas da escola, com parte do corpo docente, a direção, os projetos desenvolvidos e o perfil de cada turma, bem como as deficiências de aprendizagem dos alunos e suas perspectivas para o futuro. Nos momentos de interação e diálogo dos bolsistas com os alunos do terceiro ano do ensino médio regular, estes últimos revelaram insegurança em relação ao ENEM e exames vestibulares, afirmando que não se sentiam preparados para a realização das provas. A possibilidade de ingressar em uma universidade representava para eles um sonho distante, impossível de se tornar real. E foi justamente neste contexto, que ocorreu a ideia da criação do Projeto ENEM.

\section{O desenvolvimento do Projeto ENEM}

Neste projeto buscou-se o direcionamento pelas questões: o que é importante no ensino da disciplina escolar Biologia no Ensino Médio? É a formação de indivíduos críticos, oferecendo aos jovens a habilidade de fazer relações entre os conteúdos escolares e as práticas vivenciadas no seu cotidiano e o contexto social no qual estão inseridos, ou a sua preparação para o ENEM e os exames vestibulares? De acordo com Chassot (2017, p. 63), a responsabilidade de ensinar ciências é a de transformar nossos alunos em cidadãos críticos e capazes de transformar para melhorar o mundo em que vivemos. Chassot (2003) também afirma que a ciência é uma linguagem construída pelo ser humano para explicar o mundo natural. Assim, "[...] ser alfabetizado cientificamente é saber ler a linguagem em que está escrita a natureza" (CHASSOT, 2003, p. 91). Os conhecimentos biológicos estão presentes no cotidiano dos educandos. Temas que envolvem saúde e ambiente, sexualidade, bem como termos científicos - transgênicos, células- 
tronco, clonagem, engenharia genética, vacina gênica, gordura trans, gordura saturada, LDL - são veiculados diariamente em jornais e outras mídias. Diante dos impactos das Tecnologias da Informação e da Comunicação na sociedade da informação, a formação no ensino médio com conhecimentos oriundos das ciências é relevante para os diálogos na contemporaneidade.

Em outubro de 2018 teve início na escola o Projeto ENEM, sendo um dos objetivos o ensino de conhecimentos escolares de Biologia para estudantes de seis turmas do $3^{\circ}$ ano do ensino médio regular. Os conteúdos foram selecionados pelos estudantes bolsistas do PIBID e pelos professores. Foram ministradas aulas expositivas, aplicados exercícios e produzidas vídeoaulas, disponibilizadas aos estudantes. As atividades do projeto ENEM ocorriam duas vezes na semana, no turno da tarde, já que os estudantes do $3^{\circ}$ ano regular estavam matriculados no turno da manhã. Os estudantes recebiam por correio eletrônico vídeo-aulas sobre diferentes conteúdos de Biologia. O Projeto ENEM encerrou em 2018 e 2019 com a realização de simulados com questões do ENEM e de exames vestibulares.

É importante que os estudantes da educação básica se sintam preparados para realizar os exames de seleção para o ingresso no nível superior universitário. No Projeto ENEM, além de os licenciandos ensinarem temas de biologia abordados em provas de exames anteriores do ENEM e vestibulares, buscou-se estimular a autoestima dos alunos do $3^{\circ}$ ano do ensino médio regular, de modo a ter melhores expectativas sobre o seu ingresso na universidade. Da mesma forma que se voltou para a educação básica, este subprojeto também contribuiu para que os licenciandos vivenciassem experiências e construíssem saberes na docência. Nesta escola outro subprojeto do PIBID foi desenvolvido em edital anterior, com licenciandos e professores da educação básica de diferentes disciplinas, contribuindo para ações investigativas e emancipadoras (SANTOS; LAMEGO; CRUZ, 2015).

Durante os anos de 2018 e 2019 houve o planejamento e desenvolvimento de aulas e materiais didáticos pelos bolsistas sobre temas frequentes no ENEM, tais como: vírus, bactérias, DNA, ecologia, genética mendeliana, origem da vida, evolução biológica, respiração celular, 
fotossíntese, fisiologia humana, morfologia vegetal, histologia e programas de saúde (Figura 1).

Figura 1- Cartaz elaborado em papel com conteúdos de Biologia Celular

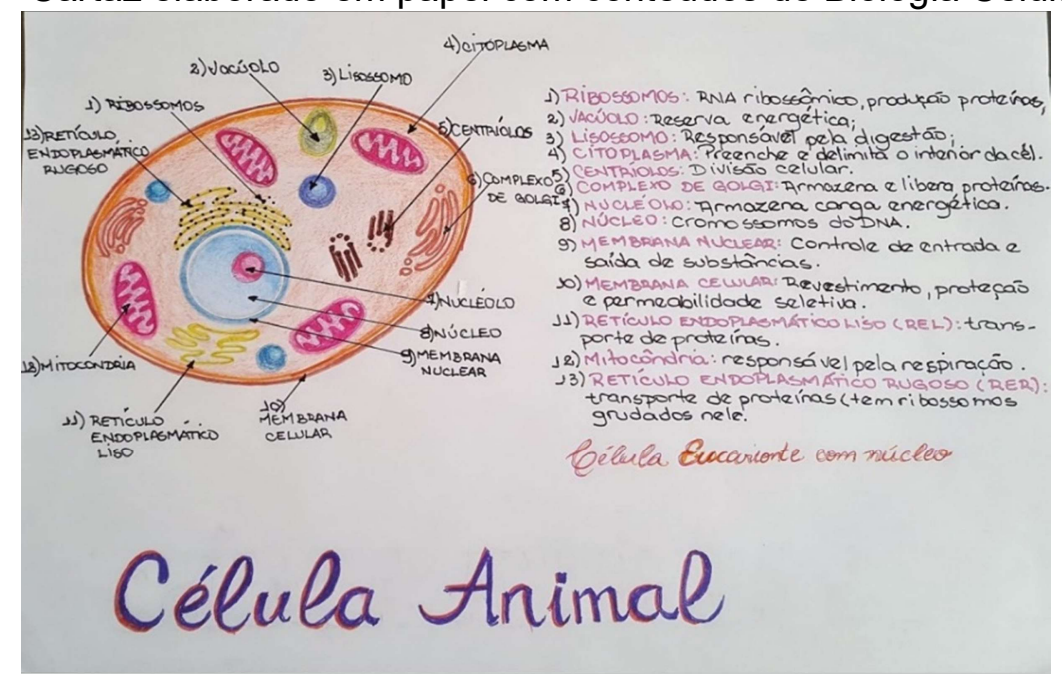

Fonte: Licenciando bolsista participante do PIBID.

Os licenciandos pibidianos foram solicitados a elaborar vídeo-aulas com até 15 minutos de duração sobre um determinado conteúdo biológico (Figuras 2 e 3), disponibilizadas aos alunos do terceiro ano do ensino médio por correio eletrônico.

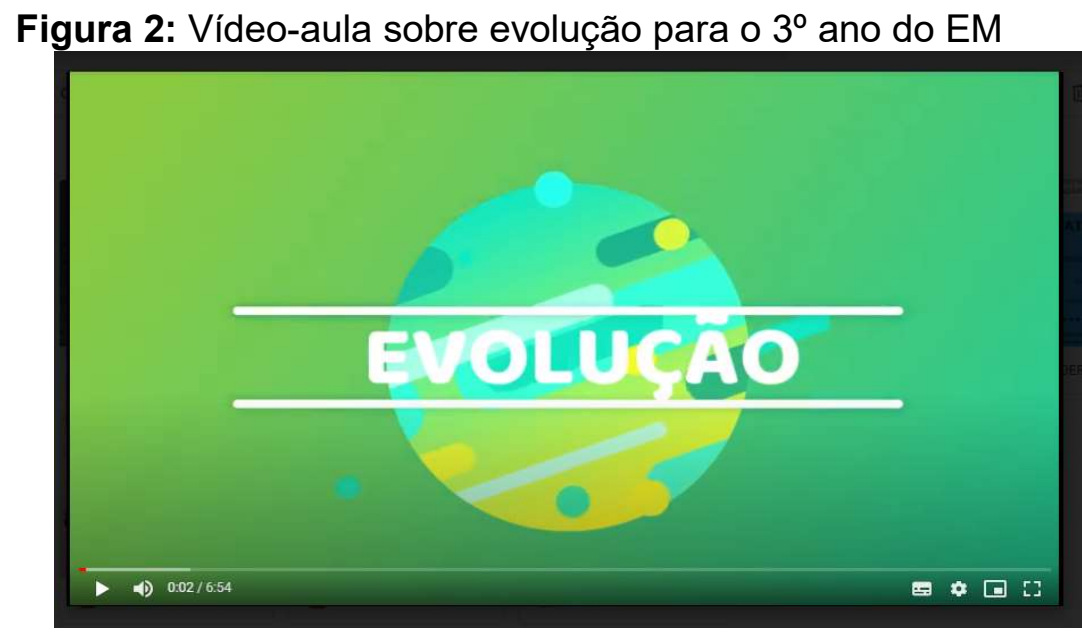

Fonte: Licenciando bolsista participante do PIBID. 
Figura 3. Imagens de vídeo-aulas produzidas por bolsistas do subprojeto Biologia -

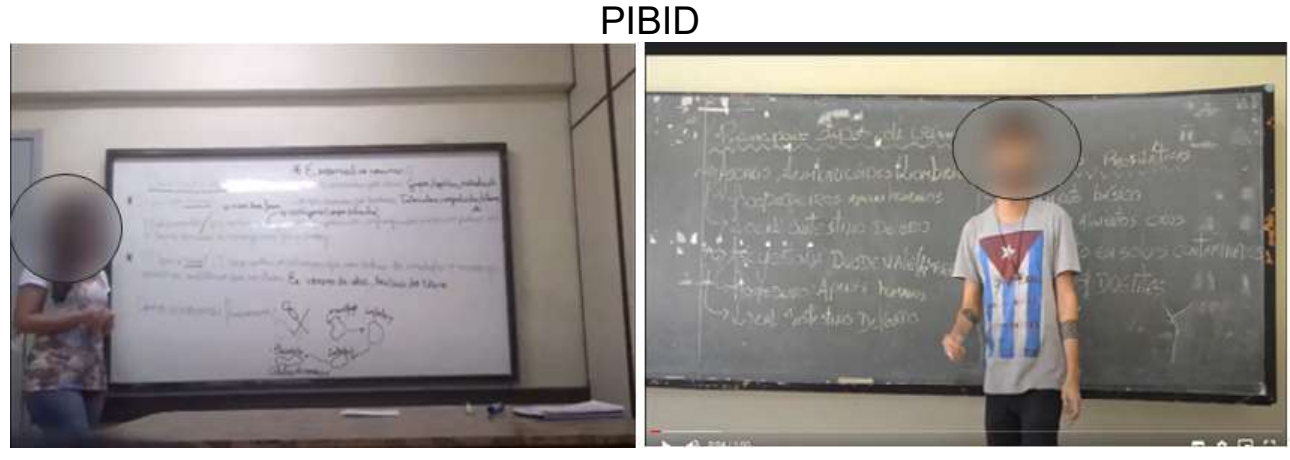

Fonte: Próprio autor.

Nas aulas do Projeto ENEM inicialmente os bolsistas ministraram aulas para as turmas do terceiro ano do ensino médio sobre um tema específico da Biologia e em seguida distribuíam textos impressos com duas questões sobre o tema abordado aos estudantes. Em cada aula dois bolsistas ficavam responsáveis pelas atividades e os alunos respondiam às questões da folha de exercícios como uma forma de avaliação da aprendizagem. As questões eram lidas e discutidas pelos bolsistas e em seguida as respostas dos alunos corrigidas.

Sobre os aspectos positivos das atividades realizadas no PIBID, destacam-se os seguintes relatos de bolsistas de iniciação à docência:

Foi uma experiência maravilhosa, tanto para eles quanto para mim; (eles) se mostraram interessados em aprender e tirar dúvidas, (eles) conseguiram enxergar o potencial que têm, isso não tem preço. Eu pude contribuir para isso! Ver essa reação deles me motivou a não desistir da carreira docente (L2).

Minhas impressões a respeito do PIBID são as melhores possíveis. Um programa que visa o incentivo à docência. Eu, como futura professora, não poderia ter experiência melhor que essa para me tornar uma profissional capacitada. O PIBID é benéfico tanto para nós universitários quanto para os alunos das escolas com que o PIBID atua (L3).

[...] O PIBID desenvolveu o meu prazer em ensinar e acreditar nos alunos, acreditar que podemos inspirá-los e motivá-los. Como professores, podemos ser o exemplo que eles precisam. Saio dessa escola com uma visão totalmente diferente de ensino do que quando cheguei, me sinto muito mais capaz para ensinar depois de conhecer e vivenciar a rotina de um docente em uma escola, existem muitos desafios a serem superados dentro da escola pública e temos que continuar a lutar por um ensino de qualidade e a incentivar os alunos (L3). 
Estes licenciandos destacaram a relevância do PIBID na sua formação inicial e para os estudantes na educação básica. Tardif (2014, p. 101) afirma que os professores, "[...] no exercício de suas funções e na prática de sua profissão, desenvolvem saberes específicos, baseados em seu trabalho cotidiano e no conhecimento de seu meio". Ampliando esta noção para a formação inicial, os licenciandos elaboram seus saberes experienciais com base em suas vivências no cotidiano escolar, em interação com outros profissionais da educação (NÓVOA, 2019), incluindo os professores da educação básica e dos cursos de licenciatura das universidades.

Os licenciandos também indicaram impactos decorrentes do Projeto ENEM na formação inicial docente:

[...] pude fazer a gravação da minha primeira vídeo aula e foi muito bom, porque desenvolvi da forma que gostaria o tema sistema nervoso e pude colocar mapa mental que pode auxiliar na fixação do assunto para os alunos que participam do Projeto ENEM (L1).

Dentro do ambiente escolar descobri uma vocação, algo que me impulsionou para estar lá, foi o prazer de poder interagir com os alunos e mudar suas perspectivas, ajuda-los a acreditar em si mesmos e que poderiam alcançar a tão sonhada Universidade; porque eu alcancei mesmo com todas as dificuldades que enfrentei para ingressar no ensino superior vindo de uma escola pública defasada e fazendo pré-vestibular popular com muita luta e contando as moedas. Eu me vi nos meus alunos, acreditei neles. [...] Foi uma honra para mim que vim de uma escola pública poder analisar e ver os problemas no ambiente e tentar corrigi-los, para uma educação libertária, uma mudança de perspectiva de aluno que virou professor (L3).

[...] As atividades que mais me marcaram foram o Projeto ENEM e o Projeto UERJ, pois pude ver e perceber o quanto esses alunos do ensino médio da escola pública se veem distantes da possibilidade de ingressar em uma universidade, principalmente pública. Isso é muito triste, de certa forma me assustou, pois vi essa realidade de frente. Meu papel como pibidiana era de incentivá-los e mostrar que, apesar de todas as dificuldades, eles seriam capazes de se tornarem universitários. (L2).

Entre os resultados positivos para os estudantes do terceiro ano do ensino médio, aponta-se que o PIBID contribuiu para uma melhor aprendizagem e maior autoestima. Segundo dados obtidos com a direção 
escolar, houve um maior número de inscritos no ENEM e em exames vestibulares do que em anos anteriores e vários foram aprovados em duas universidades públicas federais e uma universidade estadual nos cursos de: Ciências Sociais, Pedagogia, Economia, Nanotecnologia, Licenciaturas em História, Matemática e Letras. Aponta-se a potencialidade de transformação da realidade dos estudantes da educação básica com o desenvolvimento de projetos escolares e Programas que articulam a educação básica e cursos de formação de professores, como o PIBID.

\section{Considerações finais}

Os licenciandos pibidianos que chegaram à escola em agosto de 2018 saíram com outro "olhar" sobre o magistério. Seria inimaginável não esperar mudanças após três semestres imersos no cotidiano da escola, ouvindo experiências de professores, convivendo com alunos e inspetores, participando de projetos escolares, testemunhando as questões problemáticas nas proximidades da escola - como os casos de assaltos ocorridos quase que diariamente, envolvendo alunos e professores - e outros desafios que também a direção escolar enfrentou, em busca de um ensino de qualidade para todos os seus alunos.

O Projeto ENEM possibilitou que os licenciandos do PIBID tivessem suas experiências iniciais na docência, ministrando aulas com a supervisão do professor na escola. Além disso, com os resultados do Projeto ENEM, esses sujeitos perceberam mudanças na realidade escolar. "Mudar é difícil, mas é possível" (FREIRE, 2005, p. 79), e é por acreditar na possibilidade de mudança que assim se direciona a ação político-pedagógica na escola.

\section{Agradecimentos}

Os autores agradecem a CAPES pelo financiamento com bolsas.

\section{Referências}


ANDRÉ, Marli Eliza Dalmazo Afonso. Prática pedagógica: Etnografia da prática escolar. 14. ed. Campinas, SP: Papirus Editora, 2015.

BRASIL. Decreto no 7.219, de 24 de junho de 2010. Disponível em:

https://www2.camara.leg.br/legin/fed/decret/2010/decreto-7219-24-junho-2010606872-publicacaooriginal-127693-pe.html. Acesso em: 16 out. 2020.

BRASIL. Lei $N^{\circ} 9.394$ de 20 de dezembro de 1996. Disponível em: http://portal.mec.gov.br/seesp/arquivos/pdf/lei9394_Idbn1.pdf. Acesso em: 16 out. 2020.

BRASIL. Lei $n^{\circ} 11.273$, de 6 de fevereiro de 2006 - Autoriza a concessão de bolsas de estudo e de pesquisa a participantes de programas de formação inicial e continuada de professores para a educação básica. Disponível em: https://www2.camara.leg.br/legin/fed/lei/2006/lei-11273-6-fevereiro-2006540874-publicacaooriginal-42340-pl.html. Acesso em: 16 out. 2020.

BRASIL Lei $n^{\circ}$ 12.796, de 4 de abril de 2013 - Altera a Lei $n^{\circ}$ 9.394, de 20 de dezembro de 1996, que estabelece as diretrizes e bases da educação nacional, para dispor sobre a formação dos profissionais da educação e dar outras providências. Disponível em: https://www.planalto.gov.br/ccivil_03/_ato20112014/2013/lei/l12796.htm. Acesso em: 16 out. 2020.

BRASIL. Ministério da Educação. Plano de Desenvolvimento da Escola, $2007 . \quad$ Disponível em: http://portal.mec.gov.br/arquivos/Bk pde/incidocencia.html. Acesso em: 30 jul. 2020.

BRASIL. Ministério da Educação. Plano. Portaria Normativa nº38, de 12 de dezembro de 2007. Disponível em:

http://portal.mec.gov.br/arquivos/pdf/portaria pibid.pdf. Acesso em: 30 jul. 2020.

BRASIL. Plano Nacional de Educação, 2014. Disponível em: http://pne.mec.gov.br/18-planos-subnacionais-de-educacao/543-planonacional-de-educacao-lei-n-13-005-2014. Acesso em: 30 jul. 2020.

BRASIL. Ministério da Educação. Programas do MEC voltados à formação de professores, 2018.2 Disponível em: http://portal.mec.gov.br/index.php?option=com_content\&view=article\&id=15944 :programas-do-mec-voltados-a-formacao-de-professores. Acesso em: 9 set. 2020.

CAPES. Portaria $\mathbf{n}^{0}$ 096, de 18 de julho de 2013. Disponível em:

https://www.capes.gov.br/images/stories/download/legislacao/Portaria 096 18j ul13 AprovaRegulamentoPIBID.pdf. Acesso em: 30 jul. 2020. 
CHASSOT, Attico. Alfabetização científica: uma possibilidade para a inclusão social. Revista Brasileira de Educação, s/v, n. 22, p.89-100, jan/fev/mar/abr 2003.

CHASSOT, Attico. Alfabetização científica: questões e desafios para a educação. Rio Grande do Sul: Editora Unijuí, 2017.

FRANCO, Maria Lauro Puglisi Barbosa. Análise de conteúdo. 4. ed. Brasília: Liber Livro Ed., 2012,

FREIRE, Paulo. Pedagogia da autonomia: saberes necessários à prática educativa. São Paulo: Paz e Terra, 2005.

LANGUI, Rodolfo; NARDI, Roberto. Trajetórias formativas docentes: buscando aproximações na bibliografia sobre a formação de professores. Alexandria Revista de Educação Em Ciências e Tecnologia, v. 5, n. 2, p. 7-28, set. 2012.

LOCATELLI, Cleomar. A política nacional de formação docente: o programa de iniciação à docência no contexto brasileiro atual. Revista Eletrônica de Educação, v. 12, n. 2, p. 308-318, maio-ago. 2018.

MELLOUKI, M'hammed; GAUTHIER, Clermont. O professor e seu mandato de mediador, herdeiro, intérprete e crítico. Educação \& Sociedade, v. 25, n. 87, p. 537-571, maio-ago. 2004.

NÓVOA, António. Entre a formação e a profissão: ensaio sobre o modo como nos tornamos professores. Currículo sem Fronteiras, v. 19, n. 1, p. 198-208, jan.- abr. 2019.

RODRIGUES, Márcio Urel; SILVA, Luciano Duarte da; MISKULIN, Rosana Giaretta Sguerra. O processo de constituição do PIBID como política pública educacional no Brasil: um panorama da legislação e dos editais. In: Congresso Nacional e Formação de Professores, 2.; Congresso Estadual Paulista sobre Formação de Professores, 12. São Paulo: UNESP; PROGRAD, 2014, p. 79847996. Disponível em: https://repositorio.unesp.br/bitstream/handle/11449/141660/ISSN2357-78192014-7984-7996. pdf?sequence=1\&isAllowed=y . Acesso em: 9 set. 2020.

SANTOS, Maria Cristina Ferreira; LAMEGO, Caio Roberto Silveira; CRUZ, Nilza Joaquina Santiago. Formação de professores e educação ambiental: uma abordagem interdisciplinar na construção de saberes e fazeres docentes na Biologia e Geografia. Bio-grafía: escritos sobre la biología y su enseñanza, v. $\quad 8, \quad$ p. $993 \quad-\quad 1004, \quad 2015 . \quad$ Disponível em: https://revistas.pedagogica.edu.co/index.php/bio-grafia/article/view/3531. Acesso em: 16 out. 2020.

TARDIF, Maurice. Saberes docente e formação profissional. 17. ed. Petrópolis: Ed. Vozes, 2014. 
THIOLLENT, Michel. Metodologia da pesquisa-ação. 18. ed.. São Paulo: Cortez Editora, 2018.

\section{Sobre os autores}

\section{Marcos Ferreira Josephino}

ferreirajosephinomarcos@yahoo.com.br

Mestre pelo Programa de Pós-Graduação em Ensino de Ciências, Ambiente e Sociedade da Faculdade de Formação de Professores (FFP) da Universidade do Estado do Rio de Janeiro (UERJ) e licenciado em Ciências Biológicas pela FFP/UERJ. Docente no Instituto de Educação Clélia Nanci, SEEDUC-RJ. Pesquisador do Grupo de Pesquisa Ensino, Formação, Currículos e Culturas (GENFOCC/UERJ).

\section{Maria Cristina Ferreira dos Santos}

mariacristinauerj@gmail.com

Professora Associada da Faculdade de Formação de Professores (FFP) e do Instituto de Aplicação Fernando Rodrigues da Silveira (CAp) da UERJ. Licenciada em Ciências Biológicas (UERJ), Mestre em Ciências Biológicas (UFRJ) e Doutora em Educação (UFF), leciona na educação básica, graduação e pós-graduação. Docente permanente do Programa de Pós-Graduação de Ensino em Educação Básica e do Programa de Pós-Graduação em Ensino de Ciências, Ambiente e Sociedade da UERJ. Líder do Grupo de Pesquisa Ensino, Formação, Currículos e Culturas (GENFOCC/UERJ). 